\title{
Efficacy of QPM based Supplementary Nutrition on Anthropometric Indices of School Age Children
}

\author{
Kumari Sunita $^{{ }^{*}}$ and Yumnam Prabhabati Devi ${ }^{2}$ \\ ${ }^{1}$ Krishi Vigyan Kendra, Madhopur West Champaran (Dr.RPCAU Pusa) Bihar 845454, India \\ ${ }^{2}$ Krishi Vigyan Kendra Chandel ICAR Manipur Centre, India \\ *Corresponding author
}

\section{A B S T R A C T}

\begin{tabular}{l} 
K e y w o r d s \\
QPM, Biological \\
value, Protein, \\
$\begin{array}{l}\text { Essential amino } \\
\text { acid, } \\
\text { Anthropometric } \\
\text { indices, Stunting }\end{array}$ \\
Article Info \\
$\begin{array}{l}\text { Accepted: } \\
15 \text { July } 2020 \\
\text { Available Online: } \\
10 \text { August } 2020\end{array}$ \\
\hline
\end{tabular}

Keywords

QPM, Biological value, Protein,

acid,

Anthropometric

Article Info

Accepted:

15 July 2020

10 August 2020

\begin{abstract}
Maize (Zea mays L) is one of the most versatile emerging crop grown in diverse season and ecologies. Protein being the primary structural and functional component of every cell is one of the important ingredient that determines the quality of food throughout the world. The biological value of protein is increased in its new genotype-QPM by lowering zein content to $30 \%$ as a result the concentration of two essential amino acid lysine and tryptophan is increased .An on farm trial was conducted to see the efficacy of QPM based supplementary food on nutritional status of school age children(7-9years).The result showed that after feeding QPM based food as a supplement for sixteen weeks period a significant increase in anthropometric indices of nutritional status was found as compared to the group on the regular daily diet. Significant increase in both height and weight is noted in the group on the QPM supplementary diet whereas change in height was not significant in the group receiving regular daily diet however weight changed significantly after study period. Thus QPM based supplementation can be a right choice in combating malnutrition especially in the form of stunting.
\end{abstract}

\section{Introduction}

India is home to the largest number of malnourished children in the world where more than forty per cent of children remain undernourished with their growth and development impeded irrevocably throughout life (NFHS-3). Despite of many national level programs via ICDS, MDM, PDS, Annapurna program India has met only four of its millennium development goals by 2015 lacking far behind in overcoming extent of child malnutrition. Although India has achieved record food grain production the level of nutrition in our country is disturbing. As per FAO (FAO, 2013) production of quality food in adequate quantity alone may not improve nutritional status unless malnutrition is addressed by adopting a multi sectoral approach. Current nutritional interventions alone are unlikely to meet this target. The reason behind these gaps lies in India's inability to understand location specific and family specific nutritional needs of more than six lakh villages having diverse climate, cropping patterns, eating habits, 
dietary patterns, socioeconomic conditions and communication needs.

Due to high rates of under nutrition globally several strategies were devised to improve the nutritional value of some of the staple foods. These included dietary diversity, fortification, supplementation and bio fortification. Bio fortification of maize was initiated by the International Institute of Maize and Wheat Improvement Centre (CIMMYT) in 1960 and is involved in developing improved maize cultivars known as Quality Protein Maize (QPM). Maize is considered as poor man's nutri cereal however has an inbuilt drawback of being deficient in two essential amino acids lysine and tryptophan which has been overcome by developing QPM which contains twice the quantity of lysine and tryptophan making it rich in quality of protein in maize.

Poor linear growth of children manifested as stunting is the most prevalent form of malnutrition globally and is associated with higher child morbidity and mortality, poor motor and cognitive development and lower educational attainment and economic productivity. According to Third National Family Health Survey (NFHS-3) one third of Indian children are born with low birth weight, 45 per cent of children below three years of age are stunted, 23per cent are wasted and 40 per cent are under weight. Recent evidences indicate that protein and amino acids play biological roles in protein and lipid synthesis, bone elongation, and regulation of these and other processes necessary for growth.

QPM is a viable option for ensuring nutritional security. Guanaratna et al., (2010) reported that consumption of QPM leads to an increase in growth rate of height and weight by 12 and $9 \%$ respectively in infants and young children coming from population with mild to moderate under nutrition. This happened due to higher biological value of
QPM. Similarly Tessema et al., (2016) also studied the impact of QPM adoption and consumption on protein status and linear growth of children under natural settings in Ethiopia and supported that Quality Protein Maize has the potential to improve the nutritional status of the children.

Although various value added products of QPM are commercialized but these are yet far from the easy reach of this vulnerable segment of the society. Therefore this study was designed with the objective to develop QPM based supplementary foods and to study its impact of feeding on anthropometric indices of school children aged 7-9 years.

\section{Materials and Methods}

It was an on farm trial conducted in the year 2010-12 in East Champaran. The location of the study was village Karmaula, Panchayat Barwa, Motihari. Total 80 school children in the age group of 7 to 9 years (44 girls and 36 boys) participated in this study. They were again equally divided into two groups -the control group and the experimental group having forty members in each group. The control group was on regular daily diet whereas the experimental group received the supplementary nutrition in the form of QPM based Halwa in addition to the regular daily diet in school as well as at home. Each serving of halwa mix was standardized to provide $650 \mathrm{kcal}$ energy and $14 \mathrm{gm}$ protein (One third of RDA).This was served to the experimental group thrice in the week for 16weeks period.

\section{Selection of subjects}

Children in the age group of 7-9 years were selected irrespective of their gender. Children with diarrhoea, vomiting, tuberculosis, pneumonia, malaria, and with any other infectious diseases were excluded. At the time 
of enrolment consent from their mothers /guardians has been taken.

Base line survey was carried out just after selection of subjects which included child's name, sex, date of birth, weight, height, and mid upper arm circumference. Child's weight was measured using Salter Scale and recorded to the nearest $0.1 \mathrm{~kg}$. Height was measured without shoes on a height board (UNICEF) and recorded to the nearest $0.1 \mathrm{~cm}$. Mid Upper Arm Circumference (MUAC) was measured using a standard tape. MUAC was measured at the midpoint of the left arm between acromian process and the tip of the olecranon and recorded to the nearest $0.1 \mathrm{~cm}$.

\section{Method of preparation of QPM based halwa mix}

First of all QPM was sorted to remove extraneous materials and pebbles and washed in water. Processing of QPM by nixtamalization or treatment of maize with lime water is done to prepare value added product. In this process well cleaned maize grains are put in 1 per cent lime water in the ratio of $1: 2$ by mass. The mixture is heated to 85 degree $\mathrm{C}$ for 30 minutes and then left overnight. Next day the grain is dried in sunlight and then stored in container. This treatment makes the bound niacin free to get it available to the body. Besides it increases the digestibility and palatability of the maize

After alkalisation QPM was milled to grit size (bigger than semolina). QPM flour is then roasted to golden brown colour and left for cooling. Sugar was finely ground in a grinder and kept separately. QPM for this trial was procured from directorate of seed and farm, Tirhut College of Agriculture Dholi campus RAU, Pusa. Other ingredients were bought from local market. The formulations were prepared in order to meet the desired amount of energy and protein as to meet the requirement for being supplementary nutrition for children of 7-9 years in one day.

Like common maize QPM provides 11.1gm protein and $343 \mathrm{kcal}$ per $100 \mathrm{gm}(\mathrm{NIN}, 1997)$ so the requirement of $14 \mathrm{gm}$ of protein comes by taking $125 \mathrm{gm}$ QPM which would also provide about $428.75 \mathrm{kcal}$. However $55 \mathrm{gm}$ ground sugar is also added to this for sweetness as well as acceptability. Thus the weight of QPM mix per serving is 180gram whose calorific value comes to about $650 \mathrm{kcal}$ that is one third of the RDA for 7-9 yrs children.

\section{Organoleptic evaluation}

Panel of ten judges consisting of farm women and rural youths evaluated the prepared products on various parameters like colour, appearance, flavour, texture, taste and overall acceptability using nine points hedonic scale.

This pre cooked supplementary food (QPM based halwa mix) was handed over to the mothers of the subjects. Besides the demonstration was also done among the mothers to show the method of preparation and serving. The mothers were asked to feed it on every alternate day in the evening as snacks. The researcher visited weekly however one local person monitored it regularly. This process was carried out for sixteen weeks period. Mean while anthropometric measurements were taken after four weeks interval of both the groups. Measurement included weight, height, and mid upper arm circumference which were taken before and after completion of study.

\section{Measurement of outcome indicators}

The primary outcome was weight gain during 16 week feeding. Secondary outcomes included height gain, mean change in anthropometric indices of weight for age, 
height for age and weight for age, and weight for height. Other outcome indicators were changes in MUAC.

\section{Statistical analysis}

Data were analysed statistically. The paired $t$ test was done to test he mean difference between initial and final values of intervention studies. Anthropometric indices were compared with national (ICMR) and international (NCHS) standards. The respondents were further classified in to different grades of nutrition by using Waterlow's classification for height for age as given below.

\begin{tabular}{|l|l|}
\hline Waterlow's Classification & Grades of Nutrition \\
\hline $\begin{array}{l}\text { 1.<85 \% expected height for } \\
\text { age }\end{array}$ & Grade III malnutrition \\
\hline $\begin{array}{l}\text { 85-90\% expected height for } \\
\text { age }\end{array}$ & Grade II malnutrition \\
\hline $\begin{array}{l}\text { 90-95\% expected height for } \\
\text { age }\end{array}$ & Grade I malnutrition \\
\hline $\begin{array}{l}>95 \% \text { expected height for } \\
\text { age }\end{array}$ & Normal \\
\hline
\end{tabular}

\section{Weight}

Weight of the school children was compared with NCHS (1987) standard. The respondents were classified into different grades of nutrition by using Gomez classification of weight for age, which is given as under.

\begin{tabular}{|l|l|}
\hline Gomez classification & Grades of Nutrition \\
\hline $\mathbf{6 0 0 \%}$ weight for age & Grade III malnutrition \\
\hline $\mathbf{6 1 - 7 5 \%} \%$ weight for age & Grade II malnutrition \\
\hline $\mathbf{7 5 - 9 0 \% \%} \%$ weight for age & Grade I malnutrition \\
\hline $\mathbf{8 0 \% \%}$ weight for age & Grade Normal \\
\hline
\end{tabular}

The weight of a child was also related to his/her height by calculating the weight for height index. Then the school children were classified into different grades of nutrition by using Waterloo's classifications for weight for height which is given as under:

\begin{tabular}{|l|l|}
\hline Gomez classification & Grades of Nutrition \\
\hline $\begin{array}{l}\text { <70\% weight for height } \\
\mathbf{7 0 - 8 0 \%} \text { weight for } \\
\text { height }\end{array}$ & Grade III malnutrition \\
\hline $\begin{array}{l}\mathbf{8 0 - 9 0 \%} \text { weight } \\
\text { height }\end{array}$ & for malnutrition \\
\hline $\mathbf{> 9 0 \%}$ weight for height & Grade I malnutrition \\
\hline
\end{tabular}

\section{Results and Discussion}

The distribution of selected children as shown in the table 1 revealed that maximum number of children were in the age group of 7+ years in both control as well as experimental group irrespective of gender.

Anthropometric measurements employed for studying nutritional assessments of the subjects included height, weight, and mid upper arm circumference. The mean height of varied between $97.5 \mathrm{~cm}$ and $132.5 \mathrm{~cm}$ before start of feeding trial with QPM halwa which was shifted to $105 \mathrm{~cm}$ to $135 \mathrm{~cm}$ after feeding however a similar change in weight was also noted. The weight range before trial was 12$26 \mathrm{~kg}$ which became $13 \mathrm{~kg}-26.5 \mathrm{~kg}$ after trial. The range of MUAC before feeding trial was $10 \mathrm{~cm}$ to $14 \mathrm{~cm}$ which became $10 \mathrm{~cm}$ to $16 \mathrm{~cm}$ after trial.

Body measurements also changed in control group. Weight range at initial stage was $10 \mathrm{~kg}$ to $30 \mathrm{~kg}$ which became $11 \mathrm{~kg}$ to $29.5 \mathrm{~kg}$. Similarly height ranged from $90 \mathrm{~cm}$ to $135 \mathrm{~cm}$ initially and changed to $90.5 \mathrm{~cm}$ to $137 \mathrm{~cm}$. After sixteen weeks period. Mid upper arm circumference was initially ranged 11-15.4 which changed to $11-16.5 \mathrm{~cm}$. 
Table.1 Distribution of selected children age, sex and area wise

\begin{tabular}{|l|c|c|c|c|c|c|}
\hline Area & \multicolumn{3}{|c|}{ QPM Group } & \multicolumn{3}{c|}{ Regular diet Group } \\
\hline Age (Years) & Boys & Girls & Total & Boys & Girls & Total \\
\hline $\mathbf{7 +}$ & $08(20)$ & $012(30)$ & $20(50)$ & $10(25)$ & $17(42.5)$ & $27(67.5)$ \\
\hline $\mathbf{8 +}$ & $04(10)$ & $9(22.5)$ & $13(32.5)$ & $5(12.5)$ & $4(10)$ & $9(22.5)$ \\
\hline $\mathbf{9 +}$ & $03(7.5)$ & $4(10)$ & $7(17.5)$ & $3(7.5)$ & $1(2.5)$ & $4(10)$ \\
\hline
\end{tabular}

(Figure in parenthesis indicate percentage)

Table.2 Effect of Feeding QPM supplementary food on Anthropometry of school children

\begin{tabular}{|l|c|c|c|c|}
\hline School children & $\begin{array}{c}\text { QPM } \\
\text { Group }\end{array}$ & & $\begin{array}{c}\text { Regular diet } \\
\text { group }\end{array}$ & \\
\hline $\begin{array}{l}\text { Anthropometric } \\
\text { Indices }\end{array}$ & Initial & Final & Initial & Final \\
\hline Weight(kg) & $17.35 \pm 12.9$ & $18.175 \pm 11.64$ & $18.525 \pm 20.1$ & $18.925 \pm 18.648$ \\
\hline Heigh(cm) & $114.44 \pm 116.02$ & $118.695 \pm 98.122$ & $115.175 \pm 250.425$ & $117.60 \pm 245.49$ \\
\hline MUAC(cm) & $11.95 \pm 0.97$ & $13.625 \pm 2.18$ & $12.527 \pm 3.103$ & $14.45 \pm 1.89$ \\
\hline
\end{tabular}

(values represent Mean \pm SD)

Table.3 Anthropometric assessment of nutritional status of selected children (7-9 Years) before feeding QPM supplementary diet

\begin{tabular}{|l|c|c|c|c|c|c|}
\hline Area & \multicolumn{3}{|c|}{ QPM Group } & \multicolumn{3}{c|}{ Regular Diet Group } \\
\hline School children & Boys & Girls & Total & Boys & Girls & Total \\
\hline Grades Normal & & & & & \\
\hline Height for Age & $08(20)$ & $09(22.5)$ & $17(42.5)$ & $06(15)$ & $13(32.5)$ & $19(47.5)$ \\
\hline Weight for Age & $03(7.5)$ & $03(7.5)$ & $06(15)$ & $03(7.5)$ & $05(15)$ & $08(20)$ \\
\hline Weight for Height & $07(17.5)$ & $10(25)$ & $17(37.5)$ & $11(27.5)$ & $11(27.5)$ & $22(55)$ \\
\hline
\end{tabular}

Grade.1

\begin{tabular}{|l|l|l|l|l|l|l|}
\hline Height for Age & $\mathbf{0 2}(\mathbf{5})$ & $\mathbf{0 5}(\mathbf{1 2 . 5})$ & $\mathbf{0 7}(\mathbf{1 7 . 5})$ & $\mathbf{0 1}(\mathbf{2 . 5})$ & $\mathbf{0 5}(\mathbf{1 2 . 5})$ & $\mathbf{6 ( 1 5 )}$ \\
\hline Weight for Age & $06(15)$ & $09(22.5)$ & $15(37.5)$ & $06(15)$ & $10(25)$ & $16(40)$ \\
\hline Weight for Height & $10(25)$ & $09(22.5)$ & $19(47.5)$ & $02(5)$ & $06(15)$ & $08(20)$ \\
\hline
\end{tabular}

Grade.2

\begin{tabular}{|l|l|l|l|l|l|l|}
\hline Height for Age & $\mathbf{0 6}(\mathbf{1 5})$ & $\mathbf{0 7}(\mathbf{1 7 . 5})$ & $\mathbf{1 3}(\mathbf{3 2 . 5})$ & $\mathbf{0 6}(\mathbf{1 5})$ & $\mathbf{0 0}$ & $\mathbf{0 6}(\mathbf{1 5})$ \\
\hline Weight for Age & $07(17.5)$ & $08(20)$ & $15(37.5)$ & $07(17.5)$ & $04(10)$ & $11(27.5)$ \\
\hline Weight for Height & $01(2.5)$ & $02(5)$ & $03(3.7)$ & $03(7.5)$ & $01(2.5)$ & $04(10.0)$ \\
\hline
\end{tabular}


Grade.3

\begin{tabular}{|l|l|l|l|l|l|l|}
\hline Height for Age & $\mathbf{0 2}(\mathbf{5})$ & $\mathbf{0 1}(\mathbf{2 . 5})$ & $\mathbf{0 3}(\mathbf{7 . 5})$ & $\mathbf{0 5}(\mathbf{1 2 . 5})$ & $\mathbf{0 4}(\mathbf{1 0 . 0})$ & $\mathbf{0 9}(\mathbf{2 2 . 5})$ \\
\hline Weight for Age & $02(5)$ & $02(5)$ & $04(10)$ & $02(50)$ & $03(7.5)$ & $05(12.5)$ \\
\hline Weight for height & $00(0)$ & $01(2.5)$ & $01(2.5)$ & $02(5.0)$ & $04(100)$ & $06(15.0)$ \\
\hline
\end{tabular}

Figure In parenthesis indicate percentage

Table.4 Anthropometric assessment of nutritional status of selected children (7-9 Years) after feeding QPM supplementary food

\begin{tabular}{|l|l|l|l|l|l|l|}
\hline Area & \multicolumn{3}{|l|}{ QPM Group } & \multicolumn{3}{l|}{ Regular diet Group } \\
\hline School Children & Boys & Girls & Total & Boys & Girls & Total \\
\hline
\end{tabular}

Grades

Normal

\begin{tabular}{|l|l|l|l|l|l|l|}
\hline Height for Age & $\mathbf{0 9}(\mathbf{2 2 . 5})$ & $\mathbf{1 3}(\mathbf{3 2 . 5})$ & $\mathbf{2 2 ( 5 5 . 0 )}$ & $\mathbf{0 7}(\mathbf{1 7 . 5})$ & $\mathbf{1 6}(\mathbf{4 0 . 0})$ & $\mathbf{2 3}(\mathbf{5 7 . 5})$ \\
\hline Weight for Age & $04(10)$ & $05(12.5)$ & $09(22.5)$ & $05(12.5)$ & $07(17.5)$ & $12(30.0)$ \\
\hline Weight for Height & $09(22.5)$ & $12(30.0)$ & $21(52.5)$ & $08(20)$ & $15(37.5)$ & $23(57.5)$ \\
\hline
\end{tabular}

Grades.1

\begin{tabular}{|l|l|l|l|l|l|l|}
\hline Height for Age & $\mathbf{0 7}(\mathbf{1 7 . 5})$ & $\mathbf{0 5}(\mathbf{1 2 . 5})$ & $\mathbf{1 2 ( 3 0 . 0 )}$ & $\mathbf{0 7}(\mathbf{1 7 . 5})$ & $\mathbf{1 6}(\mathbf{4 0})$ & $\mathbf{2 3}(\mathbf{5 7 . 5})$ \\
\hline Weight for Age & $11(27.5)$ & $12(30)$ & $23(57.5)$ & $05(12.5)$ & $07(17.5)$ & $12(30.0)$ \\
\hline Weight for Height & $06(15)$ & $06(15)$ & $12(30.0)$ & $08(20.0)$ & $15(33.0)$ & $23(53.0)$ \\
\hline
\end{tabular}

Grades.2

\begin{tabular}{|l|l|l|l|l|l|l|}
\hline Height for Age & $\mathbf{0 2}(\mathbf{5 . 0})$ & $\mathbf{0 4}(\mathbf{1 0 . 0})$ & $\mathbf{0 6}(\mathbf{1 5 . 0})$ & $\mathbf{0 3}(\mathbf{7 . 5})$ & $\mathbf{0 2}(\mathbf{5 . 0})$ & $\mathbf{0 5}(\mathbf{1 2 . 5})$ \\
\hline Weight for Age & $03(7.5)$ & $04(10.0)$ & $07(17.5)$ & $04(10.0)$ & $03(7.5)$ & $07(17.5)$ \\
\hline Weight for Height & $03(7.5)$ & $03(7.5)$ & $06(15.0)$ & $02(15.0)$ & $02(5.0)$ & $04(10.0)$ \\
\hline
\end{tabular}

Grades.3

\begin{tabular}{|l|l|l|l|l|l|l|}
\hline Height for Age & $\mathbf{0 0}(\mathbf{0 . 0})$ & $\mathbf{0 0}(\mathbf{0 . 0})$ & $\mathbf{0 0}(\mathbf{0 . 0})$ & $\mathbf{0 4}(\mathbf{1 0 . 0})$ & $\mathbf{0 3}(\mathbf{7 . 5})$ & $\mathbf{0 7}(\mathbf{1 7 . 5})$ \\
\hline Weight for Age & $00(0.0)$ & $01(12.5)$ & $01(2.5)$ & $02(5.0)$ & $00(0.0)$ & $02(5.0)$ \\
\hline Weight for Height & $00(0.0)$ & $01(2.5)$ & $01(2.5)$ & $01(2.5)$ & $01(2.5)$ & $02(5.0)$ \\
\hline
\end{tabular}


Flow diagram of Alkali Cooking Process of QPM

Quality Protein Maize<smiles>C1CCCCC1</smiles>

Soak in $0.1 \%$ lime water<smiles>C1CCCCC1</smiles>

Give heat treatment at simmering for $30 \mathrm{~min}$<smiles>C1CCCCC1</smiles>

Remove the vessel and leave for overnight<smiles>C1CCCCC1</smiles>

Next morning, wash 3-4 times to remove lime<smiles>C1CCCCC1</smiles>

Dry in sunlight<smiles>C1CCCCC1</smiles>

Keep in container

Fig.1 In parenthesis indicate percentage

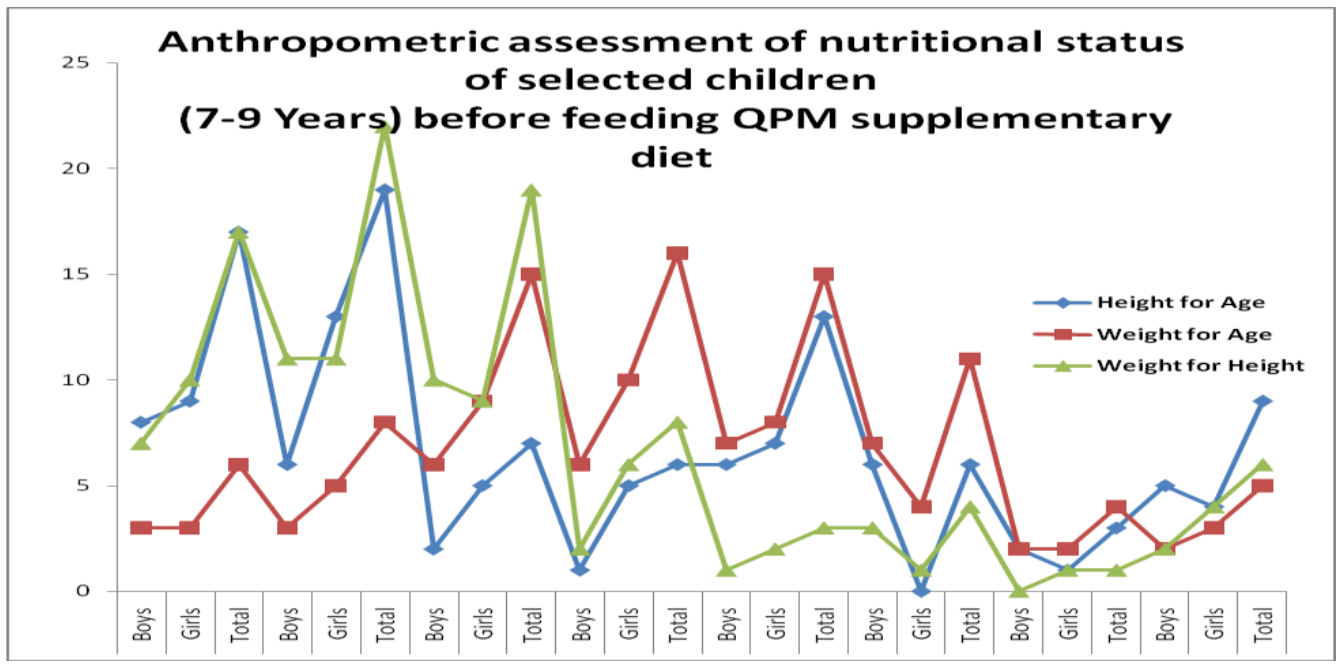


Fig.2

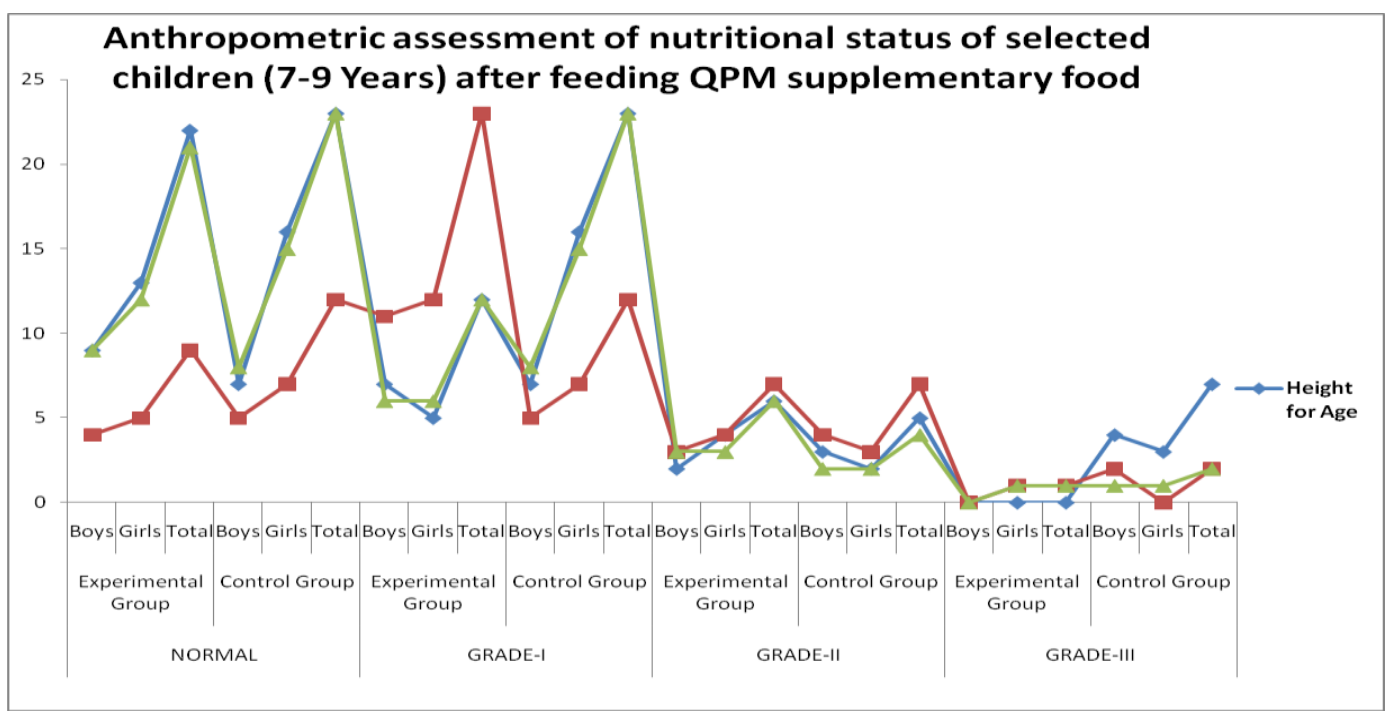

As food has the direct influence on anthropometric measurements and growth. It is expected that it will vary with feeding intervention. Table 2 indicate the impact of supplementary feeding on body measurements. On an average the height of QPM fed group was increased to $118.69 \mathrm{~cm}$ with the per cent increase of 3.7 which was statistically significant while in regular diet group(control) change in height was non significant. Increase in weight was significant in both the group while mid upper arm circumference was non significant in both the groups during the period studied.

Categorisation of children based on various indices after intervention is depicted in table 3 and table 4. After sixteen weeks supplementation a clear and significant shift was evident in severe form of malnutrition to mild form of malnutrition in QPM fed group (Fig. 1 and 2).

In conclusion the Children are the human resource and asset of the country. It is essential therefore that children are allowed to grow in an environment of optimum nutrition. To reduce childhood stunting there is an urgent need of agricultural interventions on nutrition. Quality protein maize has the potential to improve he nutritional status due to its high biological value. Value added products prepared from QPM can help in increasing food availability adding variety to it and make the diet rich in micronutrients with affordable prices and help to eradicate hunger and poverty. However there are important challenges in ensuring appropriate adoption and use of QPM.

\section{References}

FAO (2013) Guidelines for measuring household and individual dietary diversity. Nutrition and Consumer Protection Division, Food and Agriculture Organization of the United Nations. Rome, Italy.

Guanarathna, N.S., De Groote, H, Nestel, P., Pixley, K. V and Mc Cabe, G.P. (2010). A meta analysis of community level studies on quality protein maize. Food Policy.35:202-210.

ICMR (1990) Nutrient requirement and recommended dietary allowances for Indians - a report of the exert group of 
the ICMR, NIN, Hyderabad.

Tessema, M. Nilupa, S. G., Katherine, D., Jessica, L. C., M. McConnel., D. Belayneh, I.D. Brouwer, and H. D. Groote (2016) BMC Nutrition 2:54DOI 10.1186/s40795-016-0089 z.

NCHS (1987) Anthropometric reference data and prevalence of overweight US 197680. Vital and health statistics, series 11,
N 238, DHHS PubN. (PHS) 87-1168. Cited by ICMR, 1990

National family health survey (NFHS-3) (2005-06) Ministry of health and family welfare Government of India.

NIN (2017) Nutrition tllas (2017) http://218.248.6.39/nutrients atlas /home. php.

\section{How to cite this article:}

Kumari Sunita and Yumnam Prabhabati Devi. 2020. Efficacy of QPM based Supplementary Nutrition on Anthropometric Indices of School Age Children. Int.J.Curr.Microbiol.App.Sci. 9(08): 1229-1237. doi: https://doi.org/10.20546/ijcmas.2020.908.138 